\title{
Characterization of mitochondrial genome of sea cucumber Stichopus horrens: A novel gene arrangement in Holothuroidea
}

\author{
FAN SiGang $^{1,2}$, HU ChaoQun $^{1 *}$, WEN Jing $^{3} \&$ ZHANG LvPing ${ }^{1}$ \\ ${ }^{1}$ Key Laboratory of Marine Bio-resources Sustainable Utilization, Key Laboratory of Applied Marine Biology of Guangdong Province and \\ Chinese Academy of Sciences, South China Sea Institute of Oceanology, Chinese Academy of Sciences, Guangzhou 510301, China; \\ ${ }^{2}$ Graduate University of Chinese Academy of Sciences, Beijing 100049, China; \\ ${ }^{3}$ Department of Biology, Zhanjiang Normal University, Zhanjiang 524048, China
}

Received January 31, 2011; accepted February 13, 2011

\begin{abstract}
The complete mitochondrial DNA sequence contains useful information for phylogenetic analyses of metazoa. In this study, the complete mitochondrial DNA sequence of sea cucumber Stichopus horrens (Holothuroidea: Stichopodidae: Stichopus) is presented. The complete sequence was determined using normal and long PCRs. The mitochondrial genome of Stichopus horrens is a circular molecule 16257 bps long, composed of 13 protein-coding genes, two ribosomal RNA genes and 22 transfer RNA genes. Most of these genes are coded on the heavy strand except for one protein-coding gene (nad6) and five tRNA genes $\left(t R N A^{\operatorname{Ser}(U C N)}, t R N A^{G l n}, t R N A^{A l a}, t R N A^{\text {Val }}, t R N A^{A s p}\right)$ which are coded on the light strand. The composition of the heavy strand is $30.8 \% \mathrm{~A}, 23.7 \% \mathrm{C}, 16.2 \% \mathrm{G}$, and $29.3 \% \mathrm{~T}$ bases (AT skew=0.025; GC skew=-0.188). A non-coding region of $675 \mathrm{bp}$ was identified as a putative control region because of its location and AT richness. The intergenic spacers range from 1 to 50 bp in size, totaling $227 \mathrm{bp}$. A total of 25 overlapping nucleotides, ranging from 1 to $10 \mathrm{bp}$ in size, exist among 11 genes. All 13 protein-coding genes are initiated with an ATG. The TAA codon is used as the stop codon in all the protein coding genes except nad3 and nad4 that use TAG as their termination codon. The most frequently used amino acids are Leu (16.29\%), Ser $(10.34 \%)$ and Phe $(8.37 \%)$. All of the tRNA genes have the potential to fold into typical cloverleaf secondary structures. We also compared the order of the genes in the mitochondrial DNA from the five holothurians that are now available and found a novel gene arrangement in the mitochondrial DNA of Stichopus horrens.
\end{abstract}

complete mitochondrial DNA, Stichopus horrens, gene arrangement, Holothuroidea

Citation: Fan S G, Hu C Q, Wen J, et al. Characterization of mitochondrial genome of sea cucumber Stichopus horrens: A novel gene arrangement in Holothuroidea. Sci China Life Sci, 2011, 54: 434-441, doi: 10.1007/s11427-011-4168-8

With few exceptions, all animal mitochondrial DNAs (mtDNA) contain 37 genes that include 13 protein coding genes (PCGs), two RNA genes (12S RNA and 16S RNA), and 22 tRNA genes necessary for translation of the proteins coded by the mtDNA [1]. Because of its compact size, multiple copy status in a cell, rapid evolutionary rate and lack of recombination, mtDNA has been extensively used as a marker for evolutionary and genetic diversity studies and

*Corresponding author (email: cqhu@scsio.ac.cn) for the identification of species [2]. Studies into the phylogenetic relationship of metazoans based on mitochondrial genomic sequences have become increasingly popular [3,4]. In addition to mtDNA sequence data, the order of the mito-

\footnotetext{
Abbreviations: atp6 and 8, ATPase subunits 6 and 8; cob, cytochrome b; coxl-3, cytochrome c oxidase subunits I-III; nadl-6 and $4 L$, NADH dehydrogenase subunits 1-6 and 4L; srRNA and lrRNA, small and large subunits ribosomal RNA; tRNA, transfer RNA (tRNA) genes; mtDNA: mitochondrial DNA; bp, base pair(s); L1, tRNA ${ }^{\operatorname{Leu}(C U N)} ; L 2, t R N A^{\operatorname{Leu}(U U R)} ; S 1$, $t R N A^{\operatorname{Ser}(A G N)} ; S 2, t R N A^{\operatorname{Ser}(U C N)}$.
} 
chondrial genes in the sequence has received extensive attention as a phylogenetic marker [1,5-7]. Major rearrangements have been found in the mtDNA of echinoderms and comparisons of these gene arrangements have great potential for resolving some of the deepest branches of echinoderm phylogeny [5,8-12].

The class Holothuroidea, also known as sea cucumber, is one of five echinoderms. It includes more than 1400 described species around the world [13]. However, the phylogenetic relationships of these holothurians have not been fully resolved [14]. Because of a fundamental assumption that shared gene arrangements imply common ancestry, a comparison of the gene arrangements in holothurians mtDNA may resolve contentious evolutionary relationships [15].

Stichopus horrens is found in the Pacific Ocean from Malaysia to the Society Islands, around French Polynesia, and from southern Japan and Hawaii to New Caledonia [16]. The body of $S$. horrens is grey-brown with irregular grey-white spots [16]. It is cryptic and lethargic by day, and can be found in cracks, caves and crevasses in the rocky substrate at night [17]. It is used as food in China [18].

In this study, we sequenced the complete mitochondrial genome of Stichopus horrens and, by comparing S. horrens mtDNA with the mtDNA from four other holothurians, found a novel gene arrangement in the Holothuroidea class. The present study contributes new data which could be used for both genomic and evolutionary research on Holothuroidea.

\section{Materials and methods}

\subsection{Sample collection and identification}

Adult $S$. horrens were collected subtidally by scuba diving in the Xisha islands, Hainan Province, China. The samples were fixed in $100 \%$ ethanol, transported to the laboratory and stored at $-20^{\circ} \mathrm{C}$. Ossicles were observed by scanning electronic microscopy (SEM). The dorsal body walls were treated with $10 \%$ sodium hypochlorite solution for 1-2 min. The digests were then rinsed four times in distilled water, dried, coated with gold-palladium in a sputter coater (Hitachi, E-1010) and examined with a SEM (Hitachi, S-3400N). Species identification was based on the taxonomic descriptions of dermal ossicles by Liao [19] and Massin et al. [16].

\subsection{DNA extraction}

S. horrens DNA was extracted from about $30 \mathrm{mg}$ of sea cucumber muscle tissue using the TIANamp Marine Animals DNA Kit (Tiangen Biotech Co. Ltd., China) and stored at $-20^{\circ} \mathrm{C}$ until required.

\subsection{PCR amplification and sequencing}

The sequence of the complete mitochondrial genome of $S$. horrens was determined using normal and long PCRs. All PCRs were performed using a PTC-100 thermal cycler (MJ Research, USA). All primers used in this study and their thermal cycling profiles are shown in Table 1. Four short fragments of IrRNA, cox1, cob and cox3 were first amplified using three universal primers, 16sb/coIer [20], cobF424/ cobR876 [21], and cox3F/cox3R [21], and 16s1F/16s1R designed in this study (Table 1). The reaction mixtures contained $1 \mu \mathrm{g}$ of extracted template DNA, $0.2 \mu \mathrm{mol} \mathrm{L} \mathrm{L}^{-1}$ of each primer, $15 \mathrm{mmol} \mathrm{L}^{-1} \mathrm{MgCl}_{2}, 100 \mu \mathrm{mol} \mathrm{L}{ }^{-1}$ of each dNTP, 2 U of Taq DNA polymerase (TaKaRa, Japan), and $\mathrm{ddH}_{2} \mathrm{O}$ to $50 \mu \mathrm{L}$. PCR products were checked by electrophoresis on $1 \%$ agarose gel, purified using the TIANamp Mini Purification Kit (Tiangen Biotech Co. Ltd., China) and

Table 1 Primers used for amplification of the complete mitochondrial genome of the sea cucumber Stichopus horrens ${ }^{\text {a) }}$

\begin{tabular}{|c|c|c|c|c|c|}
\hline Order & Primer name & Sequence $\left(5^{\prime}-3^{\prime}\right)$ & Amplification conditions & $\begin{array}{l}\text { Product size } \\
\text { (bp) }\end{array}$ & Source \\
\hline $1^{*}$ & $\begin{array}{l}16 \mathrm{~s} 1 \mathrm{~F} \\
16 \mathrm{~s} 1 \mathrm{R}\end{array}$ & $\begin{array}{l}\text { GAGACCAGGAAAGGACAATAAGATC } \\
\text { TCGGTCTGAACTCAGATCATGTAG }\end{array}$ & $\begin{array}{c}35 \times\left(94^{\circ} \mathrm{C} 30 \mathrm{~s}, 55^{\circ} \mathrm{C} \text { for } 30 \mathrm{~s}\right. \\
\left.72^{\circ} \mathrm{C} \text { for } 1 \mathrm{~min}\right)\end{array}$ & 897 & this study \\
\hline $2^{* *}$ & $\begin{array}{l}16 \mathrm{sb} \\
\text { coler }\end{array}$ & $\begin{array}{l}\text { GACGAGAAGACCCTGTGGAGC } \\
\text { GCTCGTGTRTCTACRTCCAT }\end{array}$ & $\begin{array}{c}35 \times\left(95^{\circ} \mathrm{C} 30 \mathrm{~s}, 50^{\circ} \mathrm{C} \text { for } 30 \mathrm{~s}\right. \\
\left.72^{\circ} \mathrm{C} \text { for } 1.5 \mathrm{~min}\right)\end{array}$ & 1193 & [20] \\
\hline $3^{*}$ & $\begin{array}{l}\text { cobF424 } \\
\text { cobR876 }\end{array}$ & $\begin{array}{l}\text { GGWTAYGTWYTWCCWTGRGGWCARAT } \\
\text { GCRTAWGCRAAWARRAARTAYCAYTCWGG }\end{array}$ & $\begin{array}{c}35 \times\left(94^{\circ} \mathrm{C} 30 \mathrm{~s}, 50^{\circ} \mathrm{C} \text { for } 30 \mathrm{~s}\right. \\
\left.72^{\circ} \mathrm{C} \text { for } 1 \mathrm{~min}\right)\end{array}$ & 449 & [21] \\
\hline $4^{*}$ & $\begin{array}{l}\operatorname{cox} 3 \mathrm{~F} \\
\operatorname{cox} 3 \mathrm{R}\end{array}$ & $\begin{array}{l}\text { TGGTGGCGAGATGTKKTNCGNGA } \\
\text { ACWACGTCKACGAAGTGTCARTATCA }\end{array}$ & $\begin{array}{c}35 \times\left(94^{\circ} \mathrm{C} 30 \mathrm{~s}, 45^{\circ} \mathrm{C} \text { for } 30 \mathrm{~s}\right. \\
\left.72^{\circ} \mathrm{C} \text { for } 1 \mathrm{~min}\right)\end{array}$ & 575 & [21] \\
\hline $5^{*}$ & $\begin{array}{l}\operatorname{cox} 1-3 \mathrm{~F} \\
\operatorname{cox} 1-3 \mathrm{R}\end{array}$ & $\begin{array}{l}\text { GGCATCCAGAAGTTTACATCCT } \\
\text { TTGGAGATAGGCTTCTGTGGA }\end{array}$ & $\begin{array}{c}35 \times\left(94^{\circ} \mathrm{C} 30 \mathrm{~s}, 48^{\circ} \mathrm{C} \text { for } 30 \mathrm{~s}\right. \\
\left.72^{\circ} \mathrm{C} \text { for } 3.5 \mathrm{~min}\right)\end{array}$ & 3161 & this study \\
\hline $6^{*}$ & $\begin{array}{l}\operatorname{cox} 3-\operatorname{cobF} \\
\operatorname{cox} 3-\operatorname{cobR}\end{array}$ & $\begin{array}{l}\text { AGCAGCAGCCTGATACTGACACTTC } \\
\text { TCATACTCACTGTACGACGGTTTCTCC }\end{array}$ & $\begin{array}{c}35 \times\left(94^{\circ} \mathrm{C} 30 \mathrm{~s}, 49^{\circ} \mathrm{C} \text { for } 30 \mathrm{~s}\right. \\
\left.72^{\circ} \mathrm{C} \text { for } 4 \mathrm{~min}\right)\end{array}$ & 4880 & this study \\
\hline $7^{*}$ & $\begin{array}{l}\text { cob-16sF } \\
\text { cob-16sR }\end{array}$ & $\begin{array}{l}\text { CAACAGGGCTAGACAGAAGATACGAC } \\
\text { GGTTTAACGCTTACCGAAATGATGG }\end{array}$ & $\begin{array}{c}35 \times\left(94^{\circ} \mathrm{C} 30 \mathrm{~s}, 46^{\circ} \mathrm{C} \text { for } 30 \mathrm{~s}\right. \\
\left.72^{\circ} \mathrm{C} \text { for } 5 \mathrm{~min}\right)\end{array}$ & 5855 & this study \\
\hline
\end{tabular}

a) *, The initial step of $94^{\circ} \mathrm{C}$ for 2 min at the beginning, and final step of $72^{\circ} \mathrm{C}$ for 10 min after 35 cycles are omitted in the cycling profile of each primer pair in the table. **, The initial steps of $94^{\circ} \mathrm{C}$ for $1 \mathrm{~min}, 50^{\circ} \mathrm{C}$ for $30 \mathrm{~s}$ and $72^{\circ} \mathrm{C}$ for $1.5 \mathrm{~min}$ are omitted from the profile in the table. 
cloned into PMD18-T vectors (TaKaRa, Japan). The resultant plasmid was sequenced using the versatile primer M13-47F/M13- 47R on ABI 3730 (ABI, USA).

The whole mitochondrial genome was then amplified using a long PCR technique [22]. Three pairs of primers, cox1-3F/cox1-3R, cox3-cobF/cox3-cobR and cob-16sF/cob$16 \mathrm{sR}$, were designed based on the obtained partial sequences and the entire mitochondrial genome was amplified (Table 1). The reactions were carried out in a final volume of $50 \mu \mathrm{L}$ containing $15 \mathrm{mmol} \mathrm{L}^{-1} \mathrm{MgCl}_{2}, 0.2 \mu \mathrm{mol} \mathrm{L} \mathrm{L}^{-1}$ of each primer, $200 \mu \mathrm{mol} \mathrm{L}{ }^{-1}$ of each dNTP, $1 \mu \mathrm{g}$ of template DNA and 2.5 U of LA Taq DNA polymerase (TaKaRa, Japan). All PCR products were sequenced directly on ABI 3730 (ABI, USA) using primer walking.

\subsection{Sequence analysis}

All the obtained sequences were confirmed using the NCBI BLAST search and assembled using SeqMan software (DNAStar, Madison, USA). PCGs and ribosomal RNA genes were determined by aligning the sequences with the Apostichopus japonicus mitochondrial genome [12]. Transfer RNAs were identified using tRNAscan-SE software (version 1.21) [23] in the 'default' search mode, using the echinoderm mitochondrial genetic code, 'mito/chloroplast' source and by setting the cove cutoff score to 1 when necessary. Nucleotide composition and code usage were estimated with the MEGA4.0 program [24]. Composition skewness was calculated according to the formulas: $\mathrm{GC}$ skew $=(\mathrm{G} \%-\mathrm{C} \%) /$ $(\mathrm{G} \%+\mathrm{C} \%), \mathrm{AT}$ skew $=(\mathrm{A} \%-\mathrm{T} \%) /(\mathrm{A} \%+\mathrm{T} \%)$ [25]. The gene map of the mitochondrial genome was created with OGDRAW v1.1 [26] and modified manually.

\subsection{Analysis of the mtDNA gene order}

The complete mtDNA sequences of four other holothurians, Holothuria forskali (FN562582), Apostichopus japonicus (EU294194) [12], Parastichopus nigripunctatus (AB525762) and Cucumaria miniata (NC_005929) [27], are currently available in GenBank. These along with the complete mtDNA sequence of $S$. horrens were used to analyze the arrangement of the mtDNA genes.

\section{Results and discussion}

\subsection{Species identification}

Two different kinds of table ossicles (TB1 and TB2), $\mathrm{C}$-shaped rods and rosettes were observed in the dorsal body walls of $S$. horrens (Figure 1). The size, structure and shape of these ossicles were in agreement with previous studies $[16,19]$. The tack-like table ossicles, TB1s, are 110-130 $\mu \mathrm{m}$ across. TB2s (30-35 $\mu \mathrm{m}$ across) are smooth, perforated by 4 large central holes and 4-10 small peripheral holes. The C-shaped rods are 20-50 $\mu \mathrm{m}$ long and the rosettes are $17-30 \mu \mathrm{m}$ long. $S$. horrens is readily identified by the presence of the diagnostic distinct tack-like table ossicles (TB1) (Figure 1A) [16,28].

\subsection{Mitochondrial genome organization}

The complete mtDNA sequence of $S$. horrens was determined using normal PCR and long PCR. As found in other metazoans, the DNA is a circular double helix, $16257 \mathrm{bp}$ in length with 13 PCGs, 22 transfer RNAs and 2 ribosomal RNA genes (Figure 2 and Table 2) [1]. The size of $S$. horrens mtDNA is within the size range of holothurian mtDNA genomes sequenced to date, i.e. from 15841 bp (Holothuria forskali) to 17538 bp (Cucumaria miniata) (Table 3). Except for one PCG (nad6) and five tRNA genes $\left(t R N A^{\operatorname{Ser}(U C N)}\right.$, $t R N A^{G l n}, t R N A^{A l a}, t R N A^{V a l}, t R N A^{A s p}$ ) coded for on the light (L)-strand, all the other genes were coded for on the heavy (H)-strand (Figure 2 and Table 2). The overall base composition of the $\mathrm{H}$-strand was estimated to be $30.8 \% \mathrm{~A}, 23.7 \%$ $\mathrm{C}, 16.2 \% \mathrm{G}$, and $29.3 \% \mathrm{~T}$. The $\mathrm{G}+\mathrm{C}$ content of $S$. horrens mtDNA is $39.9 \%$, higher than that of A. japonicus/P. nigripunctatus $(38.1 \%), H$. forskali $(37.8 \%)$ and C. miniata (36.2\%) (Table 3). The AT skew for the 5 holothurian mtDNAs is positive (0.010 to 0.119$)$, indicating a slight bias toward A rather than $\mathrm{T}$ (Table 3 ). The GC skew for the 5 holothurian mtDNAs is negative $(-0.271$ to -0.055$)$, indicating the occurrence of more Cs than Gs (Table 3). The entire mtDNA sequence of $S$. horrens has been deposited in GenBank (accession number: HQ000092).

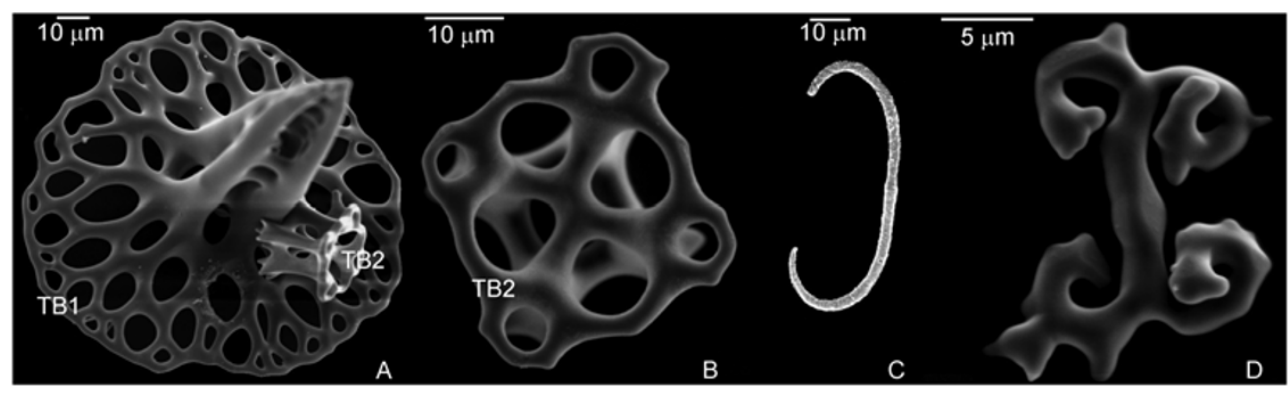

Figure 1 Dorsal ossicles of Stichopus horrens. A, TB1 and TB2; B, TB2; C, C-shape rod; D, rosettes. 


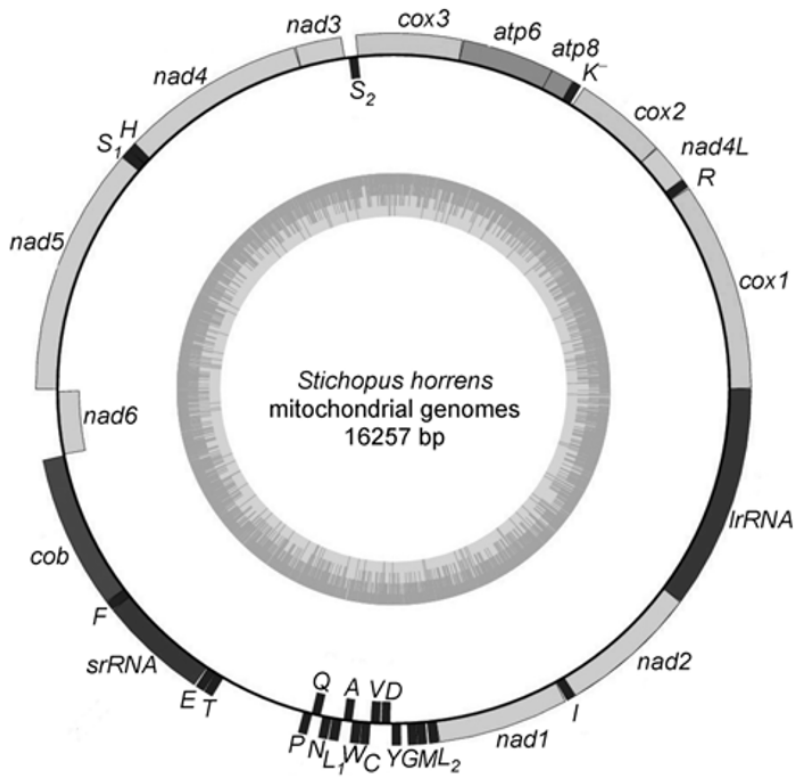

Figure 2 Gene map of the mitochondrial genome of Stichopus horrens. Genes coded on the heavy strand are on the outside of the circular gene map and genes coded on the light strand are on the inside. The inner ring displays the GC content.

\subsection{Protein-coding genes}

Together, the 13 mitochondrial PCGs in S. horrens are 11397 bp in length, longer than the PCGs in the other four holothurians (Table 3). The longest PCG in S. horrens is nad5 (1845 bp) and the shortest is atp8 (177 bp) (Table 2). Six reading frame overlaps were found within the mtDNA of S. horrens: nad4 and $t R N A^{\text {His }}$ share 10 nucleotides; atp 8 and atp6 share 7 nucleotides; $\operatorname{cox} 3$ and $t R N A^{\operatorname{Ser}(U C N)}$ share 2 nucleotides; and $t R N A^{L y s}$ and atp 8 , and $t R N A^{\operatorname{Leu}(U U R)}$ and nadl share 1 nucleotide each (Table 2). The initiation codon for all 13 PCGs is ATG (Table 2). Two genes nad3 and nad4 use TAG as the termination codon; the others, atp6, atp 8, cob, coxl-3, nadl-2, nad4L and nad5-6, all use TAA as the stop codon (Table 2). There are a total of 3799 codons in the 13 mitochondrial PCGs. The most frequently used amino acids are Leu (16.29\%), Ser (10.34\%), Ile $(9.61 \%)$ and Phe $(8.37 \%)$ (Table 4$)$. The highest GC content among the 13 PCGs of $S$. horrens mtDNA is in nad3 (43.7\%) and the lowest is in atp8 (32.8\%) (Table 5). All the PCGs have a small GC skew of -0.399 to -0.105 . Four PCGs, atp 8, nad4, nad5 and nad6, have a slight positive AT skew while the other nine PCGs have a negative AT skew (Table 5).

Table 2 Annotation of the mitochondrial genome of Stichopus horrens ${ }^{\text {a) }}$

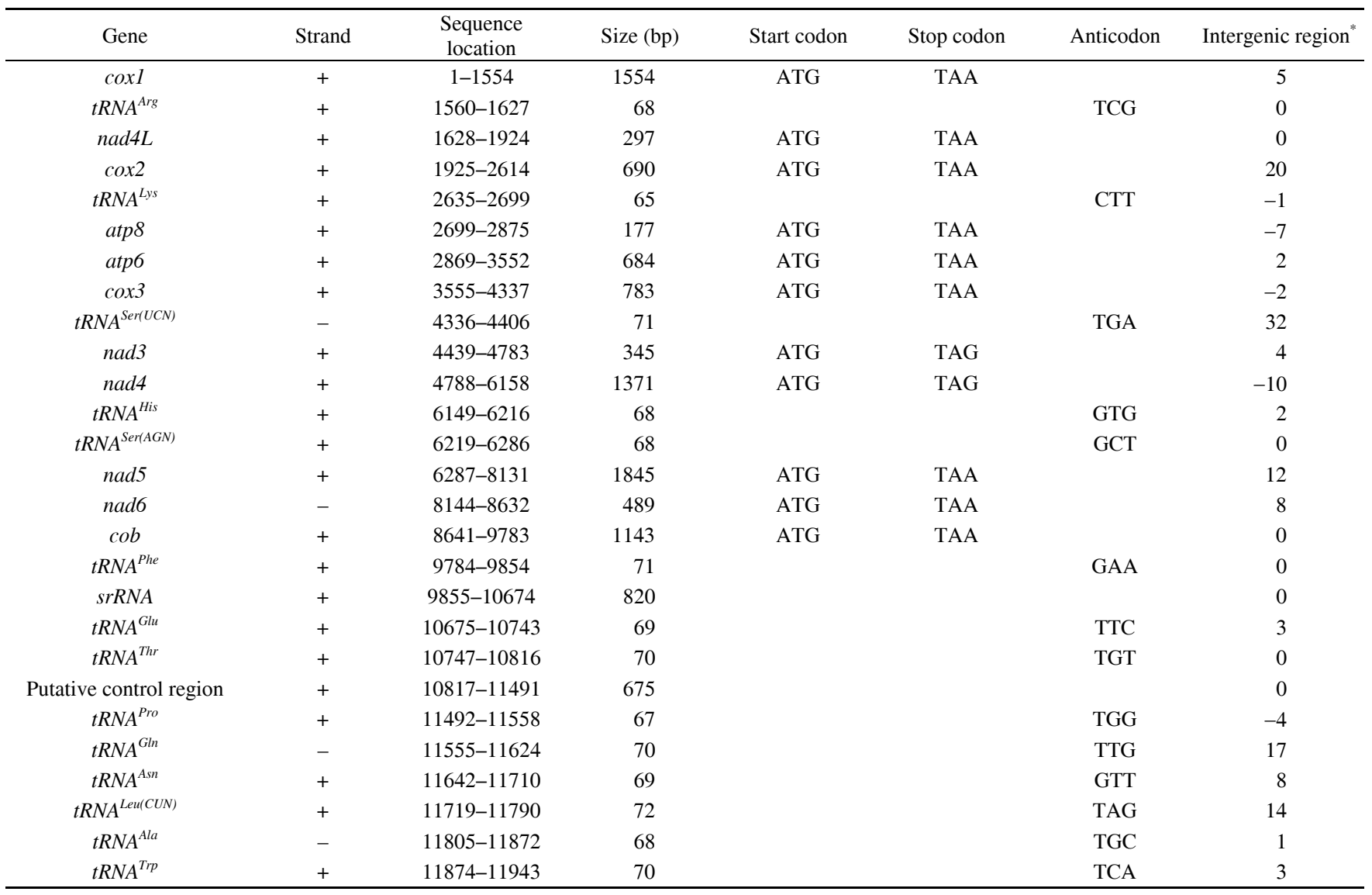


(Continued)

\begin{tabular}{|c|c|c|c|c|c|c|c|}
\hline Gene & Strand & $\begin{array}{c}\text { Sequence } \\
\text { location }\end{array}$ & Size (bp) & Start codon & Stop codon & Anticodon & Intergenic region $^{*}$ \\
\hline$t R N A^{C y s}$ & + & $11947-12013$ & 67 & & & GCA & 1 \\
\hline$t R N A^{V a l}$ & - & $12015-12086$ & 72 & & & TAC & 11 \\
\hline$t R N A^{A s p}$ & - & $12098-12165$ & 68 & & & GTC & 13 \\
\hline$t R N A^{T y r}$ & + & $12179-12246$ & 68 & & & GTA & 50 \\
\hline$t R N A^{G l y}$ & + & $12297-12366$ & 70 & & & TCC & 2 \\
\hline$t R N A^{M e t}$ & + & $12369-12437$ & 69 & & & CAT & 12 \\
\hline$t R N A^{\operatorname{Leu}(U U R)}$ & + & $12450-12522$ & 73 & & & TAA & -1 \\
\hline nadl & + & $12522-13493$ & 972 & ATG & TAA & & 7 \\
\hline$t R N A^{\text {Ile }}$ & + & $13501-13568$ & 68 & & & GAT & 0 \\
\hline $\operatorname{nad} 2$ & + & 13569-14615 & 1047 & ATG & TAA & & 0 \\
\hline IrRNA & + & $14616-16257$ & 1642 & & & & 0 \\
\hline
\end{tabular}

a) *, The numbers indicate the number of nucleotides separating the different genes. Negative numbers represent overlapping nucleotides.

Table 3 Size, composition and skew in five holothurian mitochondrial genomes

\begin{tabular}{|c|c|c|c|c|c|c|c|c|}
\hline Species & Size (bp) & A\% & $\mathrm{T} \%$ & $\mathrm{G} \%$ & $\mathrm{C} \%$ & $\mathrm{GC} \%$ & AT skew & GC skew \\
\hline \multicolumn{9}{|l|}{ Whole genome } \\
\hline H. forskali & 15841 & 31.4 & 30.8 & 16.4 & 21.4 & 37.8 & 0.010 & -0.132 \\
\hline P. nigripunctatus & 16122 & 31.7 & 30.1 & 18.0 & 20.1 & 38.1 & 0.026 & -0.055 \\
\hline A. japonicus & 16096 & 31.8 & 30.1 & 17.9 & 20.2 & 38.1 & 0.027 & -0.060 \\
\hline S. horrens & 16257 & 30.8 & 29.3 & 16.2 & 23.7 & 39.9 & 0.025 & -0.188 \\
\hline C. miniata & 17538 & 35.7 & 28.1 & 13.2 & 23.0 & 36.2 & 0.119 & -0.271 \\
\hline H. forskali & 11365 & 29.0 & 33.1 & 16.2 & 21.6 & 37.8 & -0.066 & -0.143 \\
\hline P. nigripunctatus & 11379 & 29.0 & 32.4 & 18.1 & 20.5 & 38.6 & -0.055 & -0.062 \\
\hline A. japonicus & 11379 & 29.1 & 32.3 & 18.0 & 20.6 & 38.6 & -0.052 & -0.067 \\
\hline S. horrens & 11397 & 28.3 & 31.5 & 16.0 & 24.2 & 40.2 & -0.054 & -0.204 \\
\hline C. miniata & 11339 & 32.7 & 29.6 & 14.0 & 23.7 & 37.7 & 0.050 & -0.257 \\
\hline \multicolumn{9}{|l|}{ tRNA } \\
\hline H. forskali & 1513 & 33.0 & 27.7 & 19.6 & 19.7 & 39.3 & 0.087 & -0.003 \\
\hline A. japonicus & 1518 & 32.1 & 30.1 & 18.8 & 19.0 & 37.8 & 0.032 & -0.005 \\
\hline S. horrens & 1521 & 33.1 & 29.7 & 18.7 & 18.5 & 37.2 & 0.054 & 0.005 \\
\hline C. miniata & 1506 & 34.3 & 31 & 16.8 & 17.9 & 34.7 & 0.051 & -0.032 \\
\hline \multicolumn{9}{|l|}{ rRNA } \\
\hline H. forskali & 2407 & 36.6 & 24.8 & 18.7 & 19.9 & 38.6 & 0.192 & -0.031 \\
\hline P. nigripunctatus & 2390 & 37.2 & 24.4 & 20.5 & 17.9 & 38.4 & 0.208 & 0.068 \\
\hline A. japonicus & 2387 & 37.8 & 24.3 & 19.8 & 18.1 & 37.9 & 0.217 & 0.045 \\
\hline S. horrens & 2462 & 35.9 & 24.3 & 18.6 & 21.2 & 39.8 & 0.193 & -0.065 \\
\hline C. miniata & 2200 & 41.2 & 23.9 & 15.5 & 19.5 & 35.0 & 0.266 & -0.114 \\
\hline
\end{tabular}

Table 4 Codon usage in the 13 protein-coding genes of the Stichopus horrens mitochondrial genome

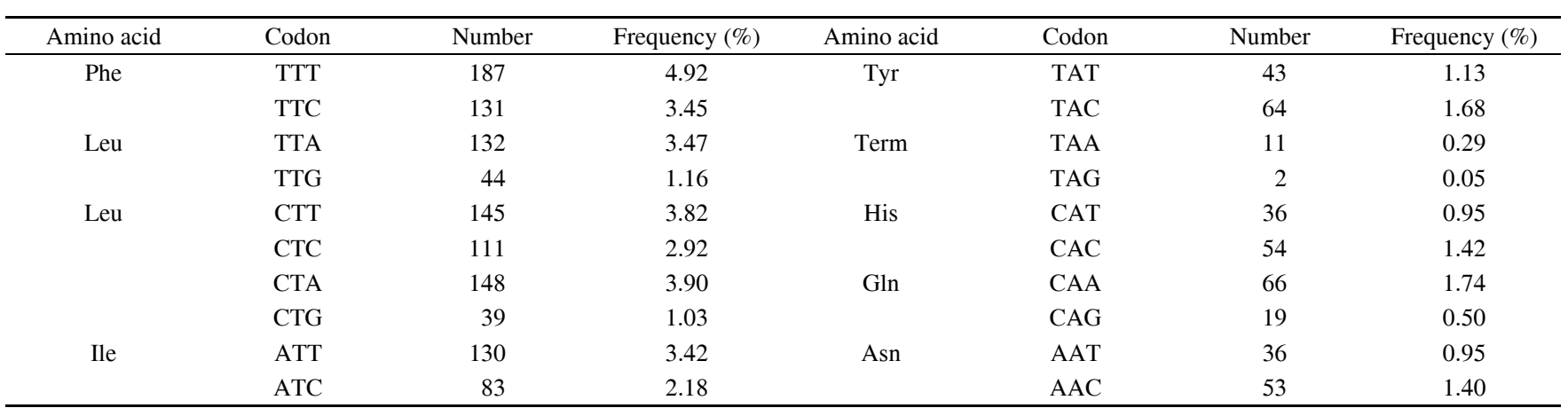




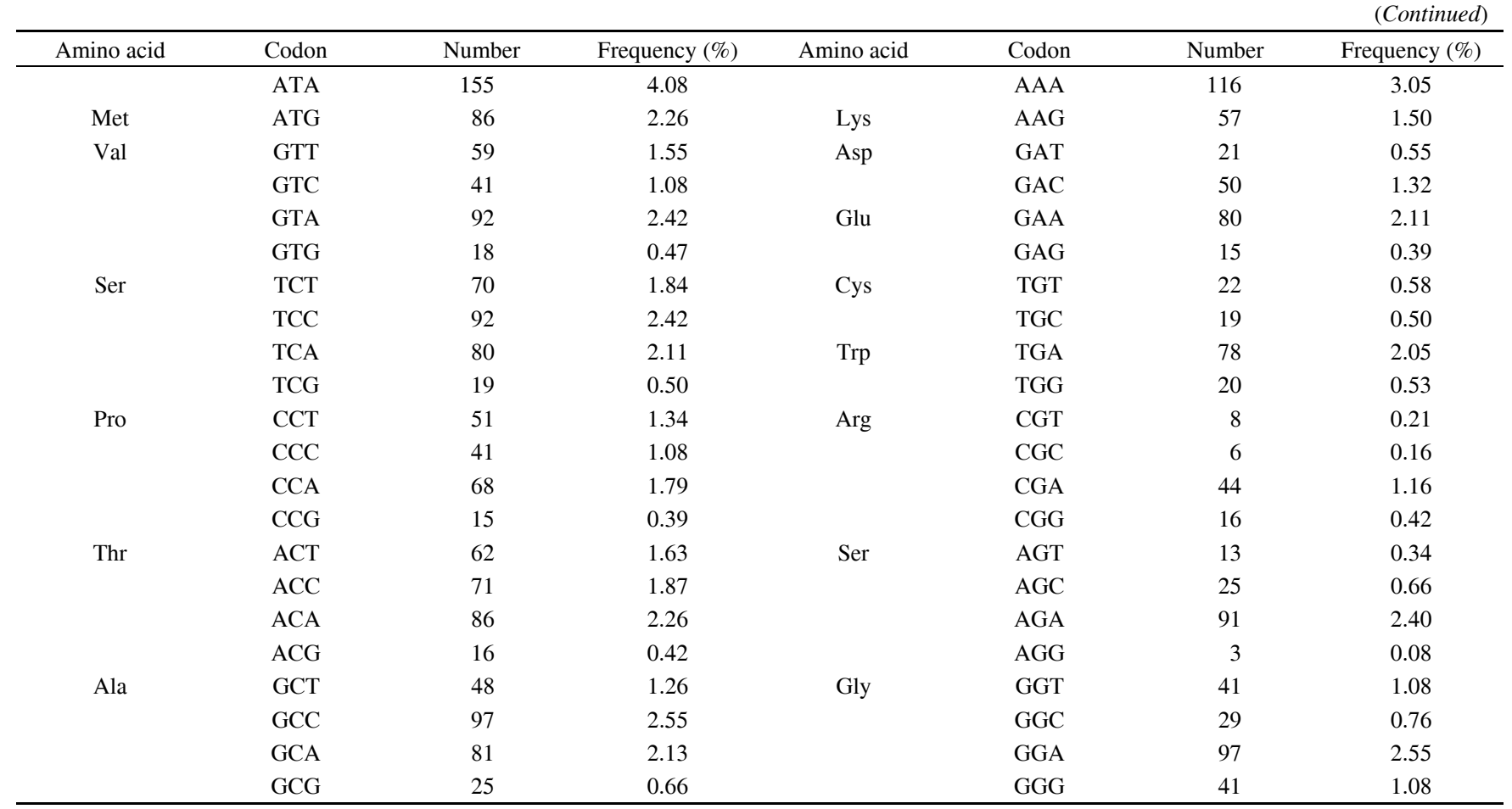

Table 5 Base composition and skew for the protein-coding genes found in the mitochondrial genome of Stichopus horrens

\begin{tabular}{|c|c|c|c|c|c|c|c|c|}
\hline \multirow{2}{*}{ Gene } & \multirow{2}{*}{ Length (bp) } & \multicolumn{5}{|c|}{ Proportion of nucleotides $(\%)$} & \multirow{2}{*}{ AT skew } & \multirow{2}{*}{ GC skew } \\
\hline & & A & $\mathrm{C}$ & $\mathrm{G}$ & $\mathrm{T}$ & $\mathrm{GC}$ & & \\
\hline $\operatorname{cox} 1$ & 1554 & 25.8 & 23.1 & 18.7 & 32.4 & 41.8 & -0.113 & -0.105 \\
\hline nad4L & 297 & 28.3 & 24.2 & 10.4 & 37.0 & 34.6 & -0.133 & -0.399 \\
\hline $\cos 2$ & 690 & 30.0 & 24.3 & 14.9 & 30.7 & 39.2 & -0.012 & -0.240 \\
\hline atp 8 & 177 & 35.6 & 20.9 & 11.9 & 31.6 & 32.8 & 0.060 & -0.274 \\
\hline atp6 & 684 & 29.7 & 24 & 13.5 & 32.9 & 37.5 & -0.051 & -0.280 \\
\hline nad3 & 345 & 23.8 & 30.1 & 13.6 & 32.5 & 43.7 & -0.155 & -0.378 \\
\hline nad4 & 1371 & 31.7 & 24.2 & 13.6 & 30.5 & 37.8 & 0.019 & -0.280 \\
\hline nad5 & 1845 & 33.2 & 24.9 & 14.5 & 27.4 & 39.4 & 0.096 & -0.264 \\
\hline nad6 & 489 & 44.6 & 25.6 & 15.1 & 14.7 & 40.7 & 0.504 & -0.258 \\
\hline$c o b$ & 1143 & 28.0 & 26.6 & 16.1 & 29.3 & 42.7 & -0.023 & -0.246 \\
\hline nad1 & 972 & 25.8 & 23.9 & 17.8 & 32.5 & 41.7 & -0.115 & -0.146 \\
\hline Mean & 877 & 30.1 & 24.7 & 15.3 & 14.9 & 39.6 & & \\
\hline
\end{tabular}

\subsection{Transfer and ribosomal RNA genes}

22 tRNA genes were found in the mtDNA of $S$. horrens and their lengths ranged from $65 \mathrm{bp}\left(t R N A^{L y s}\right)$ to $73 \mathrm{bp}$ $\left(t R N A^{\text {Leu(UUR) }}\right)$. As reported in an earlier study of A. japonicus mtDNA, $t R N A^{\text {Pro }}$ overlapped with $t R N A^{\text {Gln }}$ by 4 nucleotides (Table 2) [12]. All tRNA gene sequences can potentially fold into typical clover-leaf secondary structures. The $\mathrm{G}+\mathrm{C}$ content of the tRNAs is $37.2 \%$, within the range observed for other holothurians (Table 3).

An NCBI BLAST search found matches to the IrRNA and srRNA genes in the $S$. horrens mtDNA genome. These two rRNAs are coded for on the $\mathrm{H}$-strand. The $S$. horrens homolog of the IrRNA gene is $1642 \mathrm{bp}$ in length and lies between the PCGs nad2 and coxl. The S. horrens homolog of the $s r R N A$ gene is $820 \mathrm{bp}$ long and flanked by $t R N A^{\text {Phe }}$ and $t R N A^{G l u}$. The G+C content $(39.8 \%)$ of the S. horrens $r R N A$ genes is highest of the five holothurians.

\subsection{Non-coding regions}

The total length of the non-coding regions of the $S$. horrens mtDNA was found to be $902 \mathrm{bp}$. The largest continuous non-coding region $(675 \mathrm{bp})$ is located between $t R N A^{\text {Thr }}$ and 
S. horrens

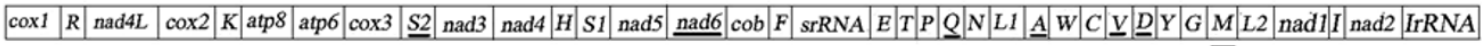

Pattern: A. japonicus, $H$. forskali and $P$. nigripunctatus

Transposition

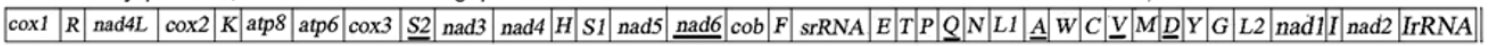

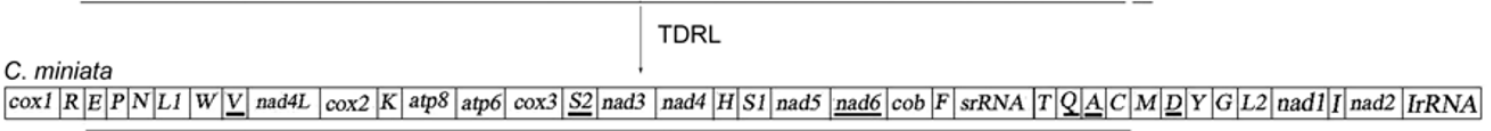

Figure 3 Linearized representation of the conserved mitochondrial gene order for five holothurians. All genes are coded for on the H-strand except those that are underlined; they are coded for on the L-strand. Gene segments are not drawn to scale.

$t R N A^{\text {Pro }}$ (Table 2). Because this region is AT-rich (AT\%= 58.1) and located in a region that is similar to the control region of $A$. japonicus mtDNA [12], this region is thought to be a putative control region in the mtDNA of $S$. horrens. The second largest non-coding region $(50 \mathrm{bp}, \mathrm{AT} \%=60)$ is located between the $t R N A^{T y r}$ and $t R N A^{G l y}$ genes.

\subsection{Gene rearrangements}

Mitochondrial gene arrangement comparison is a powerful tool for phylogenetic studies [15]. During the past decade, some research on mitochondrial gene orders in echinoderms has been reported $[1,5,8,11,12]$. Shared gene arrangements likely indicate common ancestry [11]. The mechanisms of genome rearrangement include inversion, transposition, reverse transposition and tandem duplication random loss (TDRL) [8].

In this study, five currently available holothurian mitochondrial genomes were used to analyze mtDNA gene arrangements. The order of the genes on the mitochondrial genomes of $A$. japonicus, $P$. nigripunctatus and $H$. forskali is identical. The arrangement of genes in these genomes was used as the reference in this study (Figure 3). When compared with this pattern, a single TDRL event was found in C. miniata mtDNA [5] and a transposition event which moved $t R N A^{\text {Met }}$ (gene $\mathrm{M}$ ) from the $3^{\prime}$ end of $t R N A^{V a l}$ (gene $\mathrm{V}$ ) to the 3' end of $t R N A^{G l y}$ (gene G) was found in S. horrens mtDNA (Figure 3). These results confirm earlier reports that tRNA genes may be among the most mobile elements in the mtDNA genome. This novel arrangement of Holothuroidea mitochondrial genes is reported here for the first time. The order of 21 echinoderm mitochondrial genes was compared and described by Shen et al. [12]. The gene arrangement of $S$. horrens mtDNA is also unique among the reported arrangement of echinoderm genes.

Another complete sea cucumber mitochondrial genome from the genus Stichopus was also available to us. We found that the mitochondrial gene order of the Stichopus was identical to that of $S$. horrens (date not shown). Thus, we propose that this mitochondrial gene arrangement is a feature of sea cucumbers belonging to the genus Stichopus. More sea cucumber mtDNA sequences are needed to prove this supposition.

\section{Conclusion}

In this study we presented the complete mtDNA sequence of the sea cucumber Stichopus horrens and found a novel gene arrangement in the Holothuroidea mitochondrial genome. Our results provide basic information required for the phylogenetic analyses of the holothurians that can also be applied to the echinoderms.

This work was supported by the National Key Technologies R\&D Program (Grant No. 2009BAB44B02) and the Science and Technology Program of Guangdong Province (Grant Nos. A200901E01, A200899E02 and 2009B091300155).

1 Boore J. Animal mitochondrial genomes. Nucl Acids Res, 1999, 27 : 1767-1780

2 Curole J, Kocher T. Mitogenomics: digging deeper with complete mitochondrial genomes. Trends Ecol Evol, 1999, 14: 394-398

3 Cohen B, Ameziane N E, leaume M, et al. Crinoid phylogeny: a preliminary analysis (Echinodermata: Crinoidea). Mar Biol, 2004, 144: 605-617

4 Kerr A, Janies D A, Clouse R M, et al. Molecular phylogeny of coral-reef sea cucumbers (Holothuriidae: Aspidochirotida) based on 16S mitochondrial ribosomal DNA sequence. Mar Biotechnol, 2005, 7: 53-60

5 Arndt A, Smith M. Mitochondrial gene rearrangement in the sea cucumber genus Cucumaria. Mole Biol Evol, 1998, 15: 1009-1016

6 Ren Z M, Zhu B, Ma E, et al. Complete nucleotide sequence and gene arrangement of the mitochondrial genome of the crab-eating frog Fejervarya cancrivora and evolutionary implications. Gene, 2009, 441: 148-155

7 Sankoff D, Leduc G, Antoine N, et al. Gene order comparisons for phylogenetic inference: Evolution of the mitochondrial genome. Proc Natl Acad Sci USA, 1992, 89: 6575-6579

8 Perseke M, Fritzsch G, Ramsch K, et al. Evolution of mitochondrial gene orders in echinoderms. Mol Phylogenet Evol, 2008, 47: 855-864

9 Smith M, Arndt A, Gorski S, et al. The phylogeny of echinoderm classes based on mitochondrial gene arrangements. J Mol Evol, 1993, 36: 545-554

10 Smith M, Banfield D K, Doteval K, et al. Gene arrangement in sea star mitochondrial DNA demonstrates a major inversion event during echinoderm evolution. Gene, 1989. 76: 181-185

11 Scouras A, Smith M J. A novel mitochondrial gene order in the crinoid echinoderm Florometra serratissima. Mole Biol Evol, 2001, 18: 61-73

12 Shen X, Tian M, Liu Z H, et al. Complete mitochondrial genome of the sea cucumber Apostichopus japonicus (Echinodermata: Holothuroidea): The first representative from the subclass Aspidochirotacea with the echinoderm ground pattern. Gene, 2009, 439: 79-86 
13 Smiley S. Holothuroidea. In: Microscopic Anatomy of Invertebrates, Vol 14, Echinodermata, Harrison F W, Chia F S, eds. New York: Wiley-Liss, 1994. 401-471

14 Lacey K, McCormack G P, Keegan B F, et al. Phylogenetic relationships within the class holothuroidea, inferred from 18S rRNA gene data. Mar Biol, 2005, 147: 1149-1154

15 Boore J, Brown W. Big trees from little genomes: mitochondrial gene order as a phylogenetic tool. Curr Opin Genet Dev, 1998, 8: 668-674

16 Massin C, Zulfigar Y, Hwai T S, et al. The genus Stichopus (Echi-nodermata: Holothuroidea) from the Johore Marine Park (Malaysia) with the description of two new species. Bulletin de l'Institut Royal des Sciences Naturelles de Belgique. Biologie, 2002, 72: 73-99

17 Hearn A, Pinillos F, Baseline information on the warty sea cucumber Stichopus horrens in Santa Cruz, Galapagos, prior to the commencement of an illegal fishery. Beche-de-Mer, 2006, 24: 3-10

18 Chen J. Overview of sea cucumber farming and sea ranching practices in China. Beche-de-mer, 2003, 18: 18-23

19 Liao Y L. Fauna Sinica Phylum Echinodermata Class Holothuroidea. Beijing: Science Press, 1997

20 Arndt A, Marquez C, Lambert P, et al. Molecular phylogeny of eastern Pacific sea cucumbers (Echinodermata: Holothuroidea) based on mitochondrial DNA sequence. Mol Phylogenet Evol, 1996, 6: 425-437

21 Boore J, Macey J, Medina M. Sequencing and comparing whole mi- tochondrial genomes of animals. Methods Enzymol, 2005, 395: 311-348

22 Cheng S, Chang S Y, Gravitt P, et al. long PCR. Nature, 1994, 23: 685-685

23 Lowe T M, Eddy S R. tRNAscan-SE: A program for improved detection of transfer RNA genes in genomic sequence. Nucl Acids Res, 1997, 25: 955-964

24 Tamura K, Dudley J, Nei M, et al. MEGA4: molecular evolutionary genetics analysis (MEGA) software version 4.0. Mole Biol Evol, 2007, 24: 1596-1599

25 Perna N, Kocher T. Patterns of nucleotide composition at fourfold degenerate sites of animal mitochondrial genomes. J Mol Evol, 1995, 41: $353-358$

26 Lohse M, Drechsel O, Bock R. OrganellarGenomeDRAW (OGDRAW): a tool for the easy generation of high-quality custom graphical maps of plastid and mitochondrial genomes. Curr Genet, 2007, 52: 267-274

27 Scouras A, Beckenbach K, Arndt A, et al. Complete mitochondrial genome DNA sequence for two ophiuroids and a holothuroid: the utility of protein gene sequence and gene maps in the analyses of deep deuterostome phylogeny. Mol Phylogenet Evol, 2004, 31: 50-65

28 Byrne M, Rowe F, Uthicke S. Molecular taxonomy, phylogeny and evolution in the family Stichopodidae (Aspidochirotida: Holothuroidea) based on COI and 16S mitochondrial DNA. Mol Phylogenet Evol, 2010, 3: 1068-1081

Open Access This article is distributed under the terms of the Creative Commons Attribution License which permits any use, distribution, and reproduction in any medium, provided the original author(s) and source are credited. 